\title{
Scientific Expressions in Abolfaraj Rouni's Anthology
}

\section{Mohammad Reza Najjarian*}

Department of Persian Language and Literature, Yazd University, Yazd, Iran

Email: reza_najjarian@yazd.ac.ir

How to cite this paper: Najjarian, M. R. (2016). Scientific Expressions in Abolfaraj Rouni's Anthology. Open Journal of Modern Linguistics, 6, 373-389. http://dx.doi.org/10.4236/ojml.2016.65034

Received: November 3, 2015

Accepted: May 20, 2016

Published: October 14, 2016

Copyright $\odot 2016$ by author and Scientific Research Publishing Inc. This work is licensed under the Creative Commons Attribution International License (CC BY 4.0).

http://creativecommons.org/licenses/by/4.0/

\begin{abstract}
Abolfaraj Rouni is a pioneer of a new poetry style who has influenced all the $6^{\text {th }}$ century (A.H) poets directly and indirectly. His own and his followers' poems have served as a basis for changing the Khorasani style to Iraqi style. His anthology is fraught with a variety of Arabic words and Expressions, Quranic tenets, literary figures, and poetic features. One can specifically refer to his exotic overstatements about the eulogized. To understand his poems is generally difficult because it calls for a perfect knowledge of such field as astronomy, rhetoric, logic, philosophy, theology, and the like. Here is a typical verse of such poems: Thou at rest like the poles, But in race like the moon. Abolfaraj has based his imagery upon science. He has also utilized conventions such as games of chess as well as literary issues as associations for his images. He sometimes even makes a war image using a literary issue as in the following line: Rascals seized thee from all sides, But were depunctuated by thy prowess. In this research, we have studied and explained the role of Abulfaraj Rouni in using terms and expressions derived from various fields of science that makes changing the Khorasani style to Iraqi style.
\end{abstract}

\section{Keywords}

Abolfaraj Rouni, Scientific Terms, $6^{\text {th }}$ Century Poetry

\section{Introduction}

Khorasani style, whose followers mostly were associated with Greater Khorasan, is characterized by its supercilious diction, dignified tone, and relatively literate language. The chief representatives of this lyricism are Asjadi, Farrukhi Sistani, Unsuri, and Manuchehri. Panegyric masters such as Rudaki were known for their love of nature, their verse abounding with evocative descriptions (Khorasani, 2014).

\footnotetext{
*Associate professor.
} 
The thirteenth century marks the ascendancy of lyric poetry with the consequent development of the ghazal into a major verse form, as well as the rise of mystical and Sufi poetry. This style is often called "Araqi style", (western provinces of Iran were known as Araq-e-Ajam or Persian Iraq) and is known by its emotional lyric qualities, rich meters, and the relative simplicity of its language (Ibid, 2014).

Abu-al-farajIbn-e-masoud (aka Abu-al-faraj Rouni, born in 435 A.H.) is one of the masters of Persian poetry during Ghaznavi dynasty. In fact, Abu-al-faraj can be considered as the first one in whose works far roots of Iraqi style can be found (Mahjoob, 2001; Rouni, 1968). Abu-al-faraj started to change the words style before other poets in his age. In his words, innovative metaphors and similes can be seen (Safa, 1993). In his anthology, some literary and spiritual devices, such as synonymy, rhyme, metaphor, simile and irony have been mostly used; therefore, his poems seem more complicated. He composed odes. He has also stanzas and quatrains; however, there are just three five-couplet lyrics in his anthology. Masoud Sa'ad, Anvari, Zahir Fariabi, Abolfazl Feizi, Sanaei and Rashid Al-din Vatvat were influenced by him (Rouni, 1968). Vasaf Al-Hazareh says Amir Moezi is responsible for two anthologies: Abu-al-faraj's and Masoud Sa'ad's (Shamisa, 1995). Soroush Esfahani has also replicated many odes of Abu-al-faraj (Gholamrezaee, 2002).

Abu-al-faraj is the first Persian-language poet in Pakistan in the $5^{\text {th }}$ century who was contemporary with Zahir Al-dowleh Ibrahim Ibne Masoud Ghaznein (492 - 451 A.H.) and Seif Al-Dowleh Ibne Soltan Ibrahim Naeb Al-saltaneh Lahour and Ala Al-dowle Abu Sa'ad Masoud Ibne Ebrahim Ibne Masoud Naeb Al-saltaneh (492 - 508). It is obvious that most of his life was spent in Lahour, but life did not go well with him for he always complained about livelihood shortness. He has eulogized 12 nobles, ministers, princes and emirs. His death is supposed to have been after 497 A.H. (Zahooro Din, 2005). Some consider him coming from Rouneh in Khavaran plain or Neishabour villages (Mustawfi, 2008). Oufi has also said of his history along with poets in Ghazneh and Lahour (241/2). Another story says Abu-al-faraj is originally from Rouneh Khorasan; however, he was born in Lahour, as Masoud Sa'ad was. He focuses on the justice of the eulogized along with their features, and this shows praiseworthy values of the poet. He wishes for justice until injustice departs from the world like a griffon. The justice of the commendable is mostly compared with a blooming spring, rain, a thousand heavens, and sometimes with hawks. The religious face of the commendable is still praised by the poet. Since his poems are strongly religious, lyricism is highly limited (Talebian, 1997).

The language used by Abulfaraj in his poems contains obsolete and difficult words. $\mathrm{He}$ is the one who established the insertion of scientific contents in poetry (Shamisa, 1999). The images represented by him are based on one of the mathematical, astronomical, and medical sciences. Various similes or exaggerations can be found in his anthology, which are entirely based on scientific elements. The point of comparison (resemblance) or, generally, the sequence of representation of images in his poetry is obscure and unintelligible, whether in the images arising from the current contracts and scientific matters or the ones in the realm of old fantasies (Shafiei Kadkani, 1981).

This paper aims at Abolfaraj's versification of his ideas and creation of mental asso- 
ciations for those ideas using terms and expressions derived from various fields of science.

\section{Scientific Expressions}

\subsection{Astronomical Aspects}

Astronomical terms are abundant in Abulfaraj's anthology. The praised (Mamdouh) are often analogized to Jupiter, Leo, and Venus, Parvin, Gemini, Sun, Saturn, Mercury, Capella, Calf and Sirius. In these cases, sunshine, the sun, the sky, and the moon are considered as vehicles of comparison. Using a beautiful virtual rationalization, the poet says:

When the moon sees the heavy mace on his shoulder,

He plunges in his shell, like a turtle, per month (Rouni, 1968).

He composes compound complements using similes to show that the godhead of writing and rhetoric and the master of bureaucrats and the apostles take advantage of the mind of the praised, just like the moon gaining its brightness from the sun (Rouni, 1968).

Mercury takes advantage of his mind,

Just like the moon gaining its brightness from the sun (Rouni, 1968).

Venus, being the Ferris minstrel, the third Ferris, owns two houses: Taurus, the balance (Rampouri, 1984). The praised is so sublime that the lady of cheerfulness, Venus, is just like a slave girl compared to her:

The lady of cheerfulness named as Venus,

Is just like a slave girl in thy banquet (Rouni, 1968).

The sun is considered as the forth Ferris and the house of Leo constellation. The honor of that is observable in the nineteenth grade of Capricorn (Dehkhoda, 1993). Since the eclipse of the sun occurs in the node of Zanab (the tail) complex, he says, "the way that Zanab (the tail) affects the sun results in the eclipse of the sun, and the way that meteor treats the infernal Dave and kills is just like the impact of water and fire (Sword).

The way that the meteor and Zanab (the tail) perish the Dave and the sun, Is like the way that water and fire annihilate them (Rouni, 1968).

Mars, Bahram, or the fifth Ferris is recognized to be despised and suggestive of war, hostility, and oppression. The name is derived from Markh. Merikh is the name of a kind of tree, the wood of which is used to make tinders, and it is likened to the fire considering the redness of both of them (Qalqashandi, 2008). The poet, using a beautiful virtual rationalization, implies that the eyes of Mars are red due to his insomnia caused by the fear of your shot.

Mars has red eyes and the Ferris is awake and alert, 
Since no one can relax being afraid of the arrow of thy archery (Rouni, 1968).

Jupiter, the sixth Ferris, is called a greater lucky star (Jupiter). The poet, in his poems, constantly likened the praised to Jupiter, which supports the friends:

As the sky looks at the enemies furiously,

Thou glow on thy friends like Jupiter (Rouni, 1968).

Saturn is regarded as the seventh Ferris, the head of the stars, and the greatest sinister. In Abulfaraj's poetry, Saturn is considered as the secret of distance and elevation. The power of the horse of the praised or the power of it slamming on the back of the Fish resulted in the creation of flake (According to some ancient legend the earth rests on the back of a fish) the power of his sword makes the eyes of Saturn frightful:

The power of that created flakes on the back of the Fish,

The power of his sword makes the eyes of the him frightful (Rouni, 1968).

Gheran (co-occurrence) refers to the coupling of two stars of the total of seven stars apart from the sun, in a constellation for one degree or one minute (Padshah, 1956). The conjunction of Jupiter and Venus is called "Saadeyn couple" (i.e. co-occurrence of two stars). It is the conjunction of the greatest auspiciousess and the smallest auspiciousness (Shamisa, 1998). The poet equalized the coincidence of the pen and the finger of the praised to the coupling of Venus and Jupiter:

Have thou ever seen the impact of saadeyn couple?

His pen and figure have such a kind of impact. (Rouni, 1968).

Spica is the fourteenth home of the moon. It is a big and bright star in the south of Arcturus, and, hence, there are no stars close to that. As a result, it is called "Azal" meaning the man with no weapons. This star is located in Virgo constellation (Qalqashandi, 2008). Outside of Bootes constellation, there is a big star in front of Big Dipper called "Arcturus". The star is named as such due to the name of the star near that called "the arrow of Fisher" (Nafisi, 1938). Tulip and flower together are likened to Arcturus and Spica:

Tulip and flower lying in front of each other,

Just like Ramh Spica and Spica. (Rouni, 1968).

According to the poet, Capella, with such a height and grandeur, is despicable compared to the praised.

If the praised are deducted like the ray of the sun covered in thousands of veil, It is equal to Capella, with such a height and grandeur (Rouni, 1968).

Galaxy: It is the route of the galaxy Milky Way and the celestial trail (overwhelming proof). The jeweled sword of the praised is like the Milky Way considering its length, width, and material.

His fighting blade is the second form of Milky Way,

Regarding its length, width, and essence (Rouni, 1968). 
Soheil (canopus): It is the alpha star of the spacecraft southern constellation that is the brightest star after Sirius. In areas at north latitude of higher than 37 degrees, this star is invisible. That is why, in northern Islamic lands, it does not come up in the horizon. Therefore, it turned to be used in proverbs due to its rare appearance (Mosahab, 2001). The deviation of Sohail star is 52 degrees, about 38 degrees away from the South Celestial Pole. Since the advent of the star does not last long in some areas, the poet has likened the temporary anxiety to that:

A temporary anxiety, like the brief appearance of soheil, is observable in my face,

It made me hate any distance in a foreign place (Rouni, 1968).

Zanab (the tail) is a figure in the sky which is formed by the intersection of Jouzehar meeting point. It tends toward the snake constellation. One side of that is called "the head" and the other side is named "Zanab" (Rampouri, 1984). The sword of the praised cuts the lion into two halves with just one blow. Moreover, although its head causes some pride for friends and devotees, it turns out to be a dragon facing the enemies.

His sword cuts the lion into halves with just one blow,

Although its head loves the friends; it turns out to be bad with the enemies (Rouni,

1968).

Ursa Major stars: It is the polar Pegasus constellation in the Northern Hemisphere consisting of seven stars (Mosahab, 2001). The four stars that form a rectangle are named the corpse, the whims' corpse, four mothers (Charmadar), four jewelries (Charjohar) and four bowls. The other three stars are called sisters, three sisters, three daughters, and all three daughters. Moreover, each of the stars in the great and the small Ursas are called the child of corpse (ebn-o-alnaash). The four stars of Ursa constellation are generally called the corpse (Naash), and they are named Dubhe, Merak, Phecda, and Megrez respectively. The other three stars being generally named "daughters" are known as Alioth, Mizar, and Alkaid (Dehkhoda, 1993). The poet uses astrological terms in eulogical prayers hoping that the corps of the praised turn to be like the small Ursa (Banat-e-al Naash-e-alsoghra) who can take advantage of the great Ursa (Banat-e-al Naash-e-alkobra). Abulfaraj's mental picture represents the spacial placement of the small Ursa against the great Ursa:

I wish that, like the small Ursa in a journey,

The bowls of his army were one hundred and fifty (Rouni, 1968).

The foolish blue is the irony for the sky. Complaining about his era and living period, the poet believes that the world hates the intellectuals, and the artists are always unhappy.

This foolish blue tries to hurt,

The one who is wise (Rouni, 1968).

Calves are two bright stars in Little Dipper known as "the two brothers". These stars are representative of equality and inseparability. Shery is the name of two stars: shoara-y-obur has passed through the Majareh, and shoara-y-ghamisa (Damascene) is So- 
heil's sister. This star is less bright than Soheil (conopus) (Dehkhoda, 1993). The throne of the praised is on the top of Calves in greatness and worthiness.

His intellect and effort is higher than Jupiter and Saturn,

The throne of him is on the top of Calves (Rouni, 1968).

Polar Star is the fixed star of the North Pole that would set directions (Dehkhoda, 1993). The belt of the praised is like the moonlight that passes from east to west and brightens the horizon.

Like the polar star, thy decision is stable and unchangeable,

And like the moonlight, your moving way is brightened (Rouni, 1968).

Hamal (aries) is the first constellation of Ferris, and the honor of sun is laid in this constellation (Dehkhoda, 1993).

The major star came from Pisces to Haml. (Rouni, 1968).

Taurus, or two humps: It is the second constellation of Ferris in the form of half a cow. The sun enters this constellation in Ordibehesht. The main house of the moon is in this constellation. It is one of the two houses of Venus and the other house of Mizan (Khwārizmī, 1968). Parvin, or Thuraya, or narcissus of the world: Six stars crawled into each other like a bunch of grapes. This constellation refers to the community (Biruni, 1988). In the solar system, the stars of Taurus are divided into two groups: Parvin (Greek: peleeyadise) and Alfeniqh (male camel, Greek: Hyades) (Dehkhoda, 1993). The poet has likened the branches to Taurus on the one hand, and the dispersed and tiny blossoms to Parvin on the other hand:

The Branches of Jasmine is like Taurus,

Which has made the garden like parvin (Rouni, 1968).

Gemini (twins) is the third astronological sign in the Zodiac between May and June. One of these two horns is Mercury, and the other one is spike (Dehkhoda, 1993). The Gemini (May) receives its courage from August that is Leo:

Universe becomes systematic when the Gemini becomes courageous by Gemini (Rouni, 1968).

Also Joza (Orion, constellation from the southern hemisphere) is in service of Mamdouh (the eulogizedone):

All the big and small constellations including Gemini are in its service (Rouni, 1968).

Abulfaraj says the owner of the Crab (Moon) is bent by envy of the Mamdouh bow. Crab or cancer is the fourth astrological sign and house of the moon (Ibn Khalaf Tabrizi, 1983).

His envy bends the back of crab owner,

By which the intelligence of Zargham (lion) rider recoils (Rouni, 1968). 
He uses the name of the poet (Masoud) to create the following image:

On every trip that you are planning for traveling, according to Jupiter, it is auspicious like the meaning of his name "Masoud". Accordingly, the praised one in this ode is Ala-al Duleh Masoud. Governor of cancer is the moon. Here, the purpose of the one who is esponsible for the payment of blood money for Pisces is Jupiter or Berjis, considered as Saad-e Akbar (Omen Bigger):

While you are going on a trip, as the meaning of your name is,

Governor of cancer (Status star) is well being (Rouni, 1968).

Libra has caused longer days with shorter nights. Libra is the seventh astrological sign in the Zodiac with eight stars. It is so called because, during this time, the length of night and day is equal (Dehkhoda, 1993). Libra separated the night from day, reduced a section of day and added it tonight (Rouni, 1968).

Sagittarius is the ninth astrological sign. The glow of Saturn in Sagittarius represents a time between November and December. The colorful Sagittarius rainbow that appears in the air is called "Rostam" or "Devil's bow and arrow". Rainbow (Sagittarius) is derived from the Arabic term qozhah, which means red, green and yellow rainbow or something long. It is derived from rainbow which means long, or it is ascribed to King of cloud or attributed to king of Iranians (Mosaffa, 1987). Now the mentioned bow and arrow in Iran is called "Rostam's bow" or "Morteza Ali's bow" (Daei-al-Eslam, 1985). A colorful rainbow appearing in the air is also called "evil bow". It seems that it is attributed to evil because evil is a demon, and it is common that everything of huge value be attributed to demon. The reason for the rise of the rainbow is that the sun near the realized horizon is filled with little splashes of mass water. Therefore, there is another splash of cloud that stretches to the near vast horizon. In this case, the image of rainbow falls in the droplets secreted from the edge of the upper half of the sun. Therefore, those droplets in front of the sun and back of the sun appear as a colorful rainbow (Padshah, 1956).

Regarding all omens of Saturn in a time between November and December,

It cannot stopdrinking of the pleasure-loving king (Rouni, 1968).

Aquarius is one of the oldest constellations. According to legends, it has ruled a large area of the sky in Babylon called "sea". In this region of the sky, many constellations are near water, whivh is a vital material for humans. Aquarius is located near Cetus (the whale), Pisces (the fish), Delphinus (the dolphin), Eridanus (the river), which are the parts of what is often referred to as "the water" or "sea section of the sky" where there is a cluster of water-related constellations. People consider the constellations as the source of all life where sun passes through them when it is raining. Many ancient tribes have reports about Noah deluge in their history. Ancient Greeks also believed that this deluge was God's punishment for sinful humans. According to Greek mythology, only two people survived this natural disaster, a man named Deucalion and his wife, Pyrrha, who were not warned by God. They were also, like Noah, rescued with a ship, but when the storm subsided and the water receded, they found themselves in a desert without 
anybody. They had to re-inhabit the earth, so Zeus ordered them to throw back stones by which new men rose up from the earth. It is said that, after that, "Deucalion" converted to the constellation of "Aquarius" on the order of gods. In many maps of the stars in the heaven, Aquarius is represented as young as Ganymede, which should serve as a butler the lords of Olympus. This is why he holds Cebuano in his hands. The patient Mamdouh is more of all ages. Only the subsidiary stars of Aquarius (i.e. March and whales) are heavier than the meekness of Mamdouh, It is composed as:

Your meekness is not known by people,

Exclusively subsidiary of Aquarius is prior to it (Rouni, 1968).

Pisces is the twelfth astrological sign in the Zodiac over which Jupiter or Sagittariusis located (Dehkhoda, 1993). Responsible for the payment of blood money for Pisces is Jupiter. The poet considers the Mamdouh's spirit compeer of jupiter, among all those who are titled as "Bu Saad", associated with Saad Akbar, that is, Jupiter. It means that he was better in his profession than his compeers:

Just your spirit is compeer to the Responsible for the payment of blood money for Pisces (Jupiter) (Rouni, 1968).

\subsection{Bureaucracy Aspects}

\subsubsection{Resalat Bureaus}

Using total puns of the word "tir" (dart), Abulfaraj says if your dart hits stars, the stars will be destroyed and, therefore, secretaryship and arithmetic become incomplete and aborted:

If your dart hits secretaryship and arithmetic,

They become incomplete and aborted (Rouni, 1968).

The Mamdouh's fairness is compared to rows (stripes) that make day and night equal like sidebar lines of a book:

It fairly makes equal the day and night like sidebar lines of a table (Rouni, 1968).

\subsubsection{Estifa Bureaus}

Ragham-e Targhein (marking and writing) in Nabataeans is a line drawn by a scrivener in some locations between two sounds without length accent, and it is removing of a phrase from the Bureaus (Anvari, 1976). In Mercury in Gemini, when it glows like a jewel, it actually makes the Mamdouh shiny:

That is like a secretary in Gemini-Mercury,

That makes everything shiny (Rouni, 1968).

Any figure without a square root, like number ten, is called Assam (surd). Assam appellation means the square root of a figure cannot be obtained, like hearing things with deaf ears (Shamisa, 1995). If the Prased can say a word, even the irrational number (which is born deaf), or who is famous as dumb and deaf, can hear. Digits that do not have square roots, like number ten, obtain the correct answer: 
If he talks, the congenitally deaf like the irrational number can hear (Rouni, 1968).

\subsubsection{Writing Bureaus}

In the poet's book, the words and handwriting of Mamdouh is compared to pearls (Rouni, 1968) and day and night are compared to the table line (Rouni, 1968). Moreover, the adduct of a handwriting musk is used by Abulfaraj (Rouni, 1968). The pen used by Mamdouh is compared to an Indian blade (Rouni, 1968), treasurer, Egyptian cave, etc.:

Every word written by Mamdouh's pen is like a stamp on his enemy's brows (Rouni, 1968).

Elsewhere, he wishes anyone who is jealous of Mamdouh to be drowned in black ink:

I hope anyone who feels jealous of you becomes immersed in water, like paper in the black ink (Rouni, 1968).

The poet uses additional eloquent similes by likening the poet's ration to sensory as well as compound similes. As he says, a king's solemnity encompasses enemies like an army, as words and letters are surrounded by vowels:

You were seized by vicious left and right groups,

As words and letters are surrounded by vowels (Rouni, 1968).

According to Sufis, the letter A is one of mystical symbols and an irony of unity or nature of eternity. In his essay entitled "Al-alef" or "Al-ahadiyeh", Inbn-e Arabi writes, "Because the letter A is like number one (single) in all the current numbers, so this treatise is called Al-alef".

This usage of the letter is because A is unique among other letters; in terms of ability, it has the presence of purification; in terms of coming after something in time, it has transcendence. Everything is dependent on it, and it is not attached to anything. In his thesis called "Idioms treatise", AbdulrazzaghKashaniwtites, "The letter A refers to the nature of Allah" (Khorramshahi, 1996).

Among Abjad letters, He is the most unique, the letter A (Rouni, 1968).

Mamdouh points the strong arrow at the vision of day to make it dark,

Just like the tip of the pen that grabs the circle of the letter M (Rouni, 1968).

Dotted letters are against letters without dots, but it is in the case of Farsi letters (Dehkhoda, 1993). Accordingly:

The world is born from the world of your bounty,

Like rhyme letters that go out of the Mu'jam alphabet (Rouni, 1968).

A person who is jealous of Mamdouh is compared to a spear in a black ink, which is a bad position. An array of opacity is seen in similes (referring to the darkness of black heart and black ink):

I hope jealous hearts become dark like paper in the black water (Rouni, 1968). 


\subsubsection{Martial Bureaus}

Mamdouh's pen or Mamdouh himself or Gnglaj language has been likened to a sword. Mamdouh's sword is Zoalfaqar and zoalkhmar (a Druid or magician). The combination of water color and fire behavior is a beautiful image used by Abol Faraj, which alludes to the sword. The bow handle of Mamdouh is similar to the La hol and La, Mamdouh's bow is like the crescent, and his spear is equal to the walking stick of Moses as well as hope and life:

Expectancy is long like hope and is healthy like life,

But it is the cause of short life of his enemy (Rouni, 1968).

In another image, Rustam's bow is weaker than the Tanbuk (i.e. loose bow) of Shah:

Rustam's soft bow isinconsiderable to the prince's bow (Rouni, 1968).

Chakad, is a shield. It was "qalkhan" in Turkish and "jonna" in Arabic. The strong bumper of Shabhar (i.e. a house of idols in the outskirts of Kabul) shakes at the bump of Mamdouh's sword:

In his attack, the sturdy bumper shakes even the stronge shield of Shabhar (Rouni, 1968).

Shel was a small spear sometimes made up of two and three blades (Anvari, 1976). When the small spear of Mamdouh alights on a wolf's shoulder, its spirit will fail:

His shel alighted on the wolf's shoulder,

Then the soul of it went out (i.e. died) (Rouni, 1968).

\subsection{Backgammon and Chess}

War occurs in the column and chess. Mamdouh is the king, Farzin is the minister, and horses of Mamdouh are chess players:

There is no one like him, he is the king,

And anyone except him is Farzin (Rouni, 1968).

Nadab (recommendatory) is turns in playing backgammon. When the turns come to seven and then eleven, they are called "complete recommendatory" or "Davfarah" which is said "Vamagh" in Arabic. When it reaches seven, it is called "blood hand", and whoever passes the blood hand is the winner though not having reached eighteen yet (Ibn Khalaf Tabrizi, 1983). The poet compares the invalidity of the world and the transitory nature of man to backgammon as follows:

In the world of toys and victoms, the world is like playing backgammon by Nadab (Rouni, 1968).

Sheshdar (i.e. all the six points are each occupied by two or more checkers) is, in fact, a term used in backgammon. Sheshdar is actually six houses in the backgammon because each of the cubes plays up to six roles. So, there must be two backgammons on each of which there are twelve doors engraved. In this way, there will be six-six pairs on 
the right and left sides of each backgammon. Whenever the dice becomes locked in the door at the end of the backgammon, then it cannot escape any of the houses (Rampouri, 1984). Helplessness and bewilderment of man in the world is compared to being stuck in Sheshdarin a game like backgammon:

I am helpless and bewildered by the world,

Like a dice in Sheshdar, also beaten by the heaven just as a ball in polo (Rouni, 1968).

\subsection{Jurisprudence}

"Tatil", or unbelief in God (Tahanawi, 1996) is another concept that Abolfaraj refers to in his anthology:

Your belief is very clear, and your effort is always with abundant belief (Rouni, 1968).

Reincarnation means the soul separates from the body and goes into another body. The terms used traditionally in this regard are "naskh" (i.e. the human body), "maskh" (i.e. animals), "raskh" (i.e. plant), And "faskh" (i.e. mineral) (Tahanawi, 1996). Transmigratory people pay attention to fire and its combustion. The poet calls them unbelievers:

When the transmigratory see the glory of God,

They say Ashhadan la elaha ell allah (i.e. they come to believe in god) (Rouni, 1968).

Regarding Man Yazid (i.e. auction, bidding), selling and buying, the poet compares the sky to a board on which the stars transact. He says whoever is malevolent to Mamdouh gets unlucky:

On the board where the stars transact, the fortune of those who are malevolent to Mamdouh turns into misfortune (Rouni, 1968).

Abolfaraj's Mamdouh is similar to Jupiter (Rouni, 1968). In terms of jurisprudence, he is a child or a stupid relative who commits a murder. Paying the victim's blood money is his duty (Anvari, 1976).

\subsection{Philosophy and Theology}

Horse, which is likened to justice and wisdom, is a famous theme of transformation forming a trend for discussing intellectual concepts in the poetry of Arzaqy and Abolfaraj (Talebian, 1997). The issue is represented by the following verse:

His horse was running very fast like a blower,

It seems that it is a defini fate (Rouni, 1968).

In the opinion of philosophers, wisdom isa simple entity which is separable into essence and action (Ala-e-Albasari, 1994). The poet introduces that as the intellectual power of Mamdouh which is equal to the smell of god's mercy and even stronger than 
it:

If the power of your intellect reaches that of salsal (clay),

It will move without a soul (Rouni, 1968).

Also, the nature will not create another human like Mamdouh:

A unique man! The nature is a widow,

So it is unable to create a man like you (Rouni, 1968).

The poet describes the Mamdouh's horse, Khawaja Mansoor, as something which is hard for a fatalist to imagine how to tame without a noose (i.e. a rope that binds the hands and feet of a mulish horse):

It is difficult for a fatalist to imagine it without a rope (Rouni, 1968).

Reputation is against a substance that is related to others (Safipour, 1917). Because the essence of substance is accident, if Mamdouh is not reputed, there will be no substance:

If he is not reputed, there will be no substance in the existence (Rouni, 1968).

\subsection{Medicine}

Blessing has been likened to a bride that has a defective dowry, because gratitude is similar to a groom that is enniyn (i.e. sexually impotent). This image is hardly original (Mahjoob, 2001).

His bride (blessing) has a defective dowry because gratitude (groom) is enniyn (Rouni, 1968).

Jaundice is a disease that occurs when the ways in the liver and the bile are closed so that the gall, which has to enter the liver, flows with the blood all throughout the body. The skin of the affected people and the white of their eyes turn yellow, and the patients get atrophy. If the disease is not cured, the gall may reach the heart at any moment, which leads to death (Jorjani, 2012). In the face of Mamdouh, even brave people may catch Jaundice out of fear:

Because of fear, the face of the brave turns to the color of jaundice (Rouni, 1968).

Pockmarked, or pocky, (Dehkhoda, 1993) refers to the appearance of some plants eaten out erratically by animals such as ants in the soil:

Kinds of plants now like ants in the soil,

Because ants' movement has pockmarked those plants (Rouni, 1968).

When lead and copper are extracted from the mine, antimony is obtained from the smoke that rises. The substance is used as a medicine for eyesore. It is a deterrent of dirt often accumulating in the eye vessels. It is especially very good to use if washed (Avicenna, 1991). The horseshoe of Mamdouh is equated to a crescent, and his composite dust is antimony and a remedy for the eyes:

His horseshoe is a crescent and the dust of his composite is equal to antimony 
(Rouni, 1968).

Opium or opiate (afyun) which derives from the Greek word "apyun" is Mosbet, or having hypnogogic properties. In Arabic, it is "labanalkhashkhash" and "morqed", in Barbarian "theriac", and in Syriac "dasadmyqun" and "Shaqyqel", which means killer of the parts of body. The Persian word for it is "teryak". Its nature is cold and dry, and its coldness is at the fourth level. Its properties make it usable as a drug, astringent, dissuasive, hypnogogic, solvent, anodyne, preventive of mucus stench and corruption, and a protective substance in seasonings. It is also beneficial for most diseases of head, nerves, eyes and ears, etc. Its benefits have been proved on trips and during fatigue, for sadness or grief, and for weakness of the heart (Aghili Khorasani, 1992). Mamdouh's pen has the method of a dragon although it is a fiction. In the following verse, Tennin is the figurative reference to dragon's poison against company or vicinity:

Although his pen is opium of two hundred Tennyns (dragon),

It has the method of Tennyn (Rouni, 1968).

Basalyq is a Greek word referring to a famous vessel and great kings. Because this vessel is from the heart and the liver (Padshah, 1956), Even distinguished corps and great kings cannot get released from Mamdouh:

Mahyal, Jond, Jybal, and Basalyq show up but Bashkir Barmar cannot be released from him (Rouni, 1968).

Salvadora Persica (the wood of Arak tree) contains tannin, compounds of Sulfur and Snjryn, chlorine, chloride, Silica, Terry methyl amine, fluorine, fluoride, silica, silicon, and sodium bicarbonate that can whiten, disinfect, and clean the teeth, prevent a tooth decay and the development of plaques, prevent gum bleeding, and strengthen the gums and teeth. Salvadora Persica has flavoring fragrant oil that freshens the mouth. The anysyk acid in Salvadora Persica helps to repulse the sputum. The ascorbic acid and Sytosytrol which exist in this wood strengthen the blood vessels that feed the gum. Ansralyton in Salvadora Persica is useful in boosting the appetite and regulating the bowel movement.

Until the incense sticks and Arak is fragrant and delicious in the world (Rouni, 1968).

There are four major humors in the human body including phlegm, blood, bile and melancholy. The body runs to a decline if one of them overcomes the others. In other words, the human body remains in good health when all of those humors keep in balance. Sickness is the cruelty of one humor to another. Bile is a yellow, hot and dry humor. Ancient scientists believed that the cause of resentment and indignation is bile. Jorjani writes, "The birth of mucus is with anger, and, in summer especially in young people, yhat has to do with suffering and eating dry and hot foods" (Jorjani, 2012). Yellow bile is a disease that occurs as a result of the conquest of bile, and getting angry is its symptom (Avicenna, 1991).

I hope the evils of seven and four will be away from you so that you can lead the 
heads in the world (Rouni, 1968).

Miz, noun of Myzydan or Mykhtn means piss (Nafisi, 1938). People believe that, if

a leopard scratches someone and drops him injured and a mouse pisses on him,

the person dies (Shamisa, 1995).

If claws of a leopard grab and injure you,

He will piss on it until you die (Rouni, 1968).

Qyfal is a vessel in the arm specialized for the head and the face. It is known as Sraruy (Nafisi, 1938). Wathin is a blood vessel that feeds the heart. If it is ruptured, the person dies (Alzanji Alsajzi, 1985). Jorjani states that Qyfal includes two vessels, one in each hand. The vessels are the second pair of vessels that come up from the liver to the neck where the two vessels part from each other. One is smaller than the other, but both are lateral to the neck. Qyfal comes to the encephalon and spreads like a carpet. It gets scattered in Pecker Sporadic in order to feed it and benefits the encephalon abundantly. The vessel is finally collected and comes down like Baslyq. In some people, this landing is more hidden because it is behind the muscles but sometimes more appearant because it goes over the muscles. Anatomists say Vdjan includes two branches of Basalyq that comes up from the head, in contrast to qyfal that comes down the head. It is said that thick Vadj is Basalyq, and washy Vadj is the concentrated. This vessel in known as Qifal because is on the boundary of cubits. Qyfal provides blood for the head, eyes, nose, mouth, teeth and lips (Jorjani, 2012):

A sea is not something like your chest.

Qyfal is a valley from Wathin (vessel in the chest) (Rouni, 1968).

\subsection{Music}

Barbat, roud or Oud, is an Iranian musical instrument. It is in the category of string instruments. Barbat is the most ancient oriental instruments. Contrary to the statements of its belonging to Arabs, it is more believable that Barbat is an old Iranian instrument that, after Islam, was taken to Arab countries. Its name was then changed from Barbat to Al-Oued meaning "wood". The origin of Barbat, according to the Elamite motifs carved on the third and fourth millennia BC, is the south and south west of Iran. On the remaining metal containers and the inscriptions of the Sassanid era on which musicians are depicted, this instrument can be seen abundantly. The name ofaBarbat player is Barbad, but Bamshad, Nakisa and Ramtin, after the Sassanids and Muslim caliphs, sought to make the instrument dominant, thus spreading it throughout the Muslim world from China to Andalusia. During the reign of Abd al-Rahman II in Andalusia, Kamal al-Din Zaryab, a famous Barbat player, was invited to Andalusia, and this instrument was introduced to Spain. In this country, Zaryab expanded the Barbat and developed it by mixing this instrument with the tar (another Iranian instrument), thus making the guitar. There is annual tribute in Spain held to the name "Zaryab". Pacodelosia is the most famous guitarist in the world that composed a piece of melody called Zaryab for his commemoration (Mirsalim, 1996). The cord of this instrument is very large, stretched on a pear-shaped belly, and segmented into short categories. In such a 
way, much of the length of the cord is located along the abdomen. The top surface of the abdomen is made of wood on which latticed windows are created. Barbat has no hands, and the vault construction is short and somewhat stretched.

Thou hast thy heart and mind time on fighting time on listeningthe barbat (Rouni, 1968).

Tanbour Moarab Tonbareh (Archimedes' screw) is a Hindi word meaning bitter pumpkin. This is because the instrument was originally made out of bitter pumpkins. Rashidi Says it is named MoarabDombareh because of its similarity to a lamb tail. The book "Iran in the period of the Sassanids" says "Iranian musical instruments as mentioned by Masoudi are Oud, Nay, Tanbur, Mezmar, and Chang. Masoudi says the people of Khorasan often used a musical instrument that had seven cords. It was called zang or zanj. However, but the people of Rey and Tabarestan and Deilam liked Tanbur more. This instrument became more popular than others. The hunting ground of Khosrow in Taq-e Bostan shows that Trombone was a musical instrument in the Sassanid era that stood the first rank among other instrument. Of course, there were other instruments such as Trumpet, Tanbur, and pipe. The names of some musical instruments are in the treatise of Khosrow and his slave (Dehkhoda, 1993). Abolfaraj compares the mamdouh's ears to a Rude (an Iranian traditional instrument). In another image, he compares a pearon tree branch to the corner of Tanbur. It reads as follows:

I think in a bough of pear tree, the pear is the handle and corner (Gardana) of the Tanbur (Rouni, 1968).

\subsection{Metrical Patterns}

There exists no "Mafael" meter in modification of "Mafaiylon" in the Hazaj meter (Shams Qeis Raazi, 1994), but there is "Faoulon" meter called "blacked out and bleached Mafaiyl". So, fractionated "Mafael" is not valid unless it is used as "Faulon" as advised in the following:

The verse has been always scanned into the rhythm "Mafaylon Mafaylon Mafaiel"

(Rouni, 1968).

Poet contrasts with the ambiguous use of the word perfect to imperfect and to take advantage of If Mamdouh (commendable) is worthwhile enough, using the long meter "Motfaelon" fails to describe him adequately:

If the Prosody is to versify his generosity, long meter is not appropriate for him (Rouni, 1968).

\section{Result}

The most frequently used terms in Aboalfaraj's anthology are astronomical terms such as conjunction of Venus and Jupiter, Spica and Arctuurus, Gemini, Saturn, Zanab, and the owner of the Crab (Moon). Of course, in the twelve towers, the Virgo, Scorpius, Polaris and Pisces are not mentioned by Aboalfaraj. Medical science is his favorite. A 
few representative medical terms used in his anthology are basalyq, jaundice, the four humours, collyrium, impotency and Qyfal. Terms of prosody and music are rare in his anthology. The few musical terms include long meter, fragmentation, stretch, pitch and switch. Terms of theology and jurisprudence are rarely seen too; Auction, commerce, purchase, land-tax, metempsychosis, nullification (disbelief in God as well as custody of children).

Make up but a small collection. Similarly, the poet rarely uses the legal and philosophical terms. A few ever used are divine decree, intellect, accident and substance, compulsion, existence and non-existence. However, terms of chancery and mathematics and scribing are considerable in the images used in his poems. A few examples are Tarqyn, fair line, and incommensurable (jazreasam).

\section{References}

Aghili Khorasani, M. H. (1992). Makhzan Aladvia (2nd ed.). Tehran: Enghelabe Eslami Publications.

Ala-e-Albasari, H. A. S. (1994). Harh almostalahat Alkalaamia. Mashhad: Majma albohus al Eslamia Publications.

Alzanji Alsajzi, M. (1985). Mohazzab Alasma. Tehran: Cultural and Scientific Publishing Company.

Anvari, H. (1976). Divani Terms. Tehran: Tehran University Publication.

Avicenna, H. (1991). Qanoon Translator (Abdorrahman, S. Ed., 5th ed.). Tehran: Soroush.

Biruni, A. (1988). Al-Tafhim (Homaie, J. Ed.). Tehran: Homa.

Daei-al-Eslam, S. M. A. (1985). Farhang-e nęāmo (V 1. 2). Tehran: Danesh Publications.

Dehkhoda, A. A. (1993). Dehkhoda Dictionary. Tehran: Tehran University.

Gholamrezaee, M. (2002). Sabk Shenasi Sheare Parsi. Tehran: Jami Publication.

Ibn Khalaf Tabrizi, M. H. (1983). Burhān-i qậti‘ Tehran: Amir Kabir Publications.

Jorjani, E. E. e. H. (2012). Zakhire Khwarizmshahi. Qom: Ehyaye Tebe Tabiei.

Khorasani, S. (2014). A Review on Persian Literature. International Advances in Engineering and Technology (IAET), 5, 137-150.

Khorramshahi, B. (1996). Hafez nameh. Tehran: Elmifarhangi.

Khwārizmī, M. (1968). Mafātịh al-'ulūm (H. kadiv Jam, Trans.). Tehran: Elmi o Farhangi.

Mahjoob, M. J. (2001). Khorasani’s Style in Persian Poem. Tehran: Ferdousi Publications.

Mirsalim, S. M. (1996). The Encyclopaedia of Islam, Tehran, the Great Islamic Encyclopaedia.

Mosaffa, A. (1987). A Glossary of Astronomical Terms. Tehran: Moassesa Motaleate Farhangi.

Mosahab, G. (2001). Daeratolmaaref Farsi. Tehran: Amir Kabir Publications.

Mustawfi, H. (2008). Tarikh Gozideh (5th ed.). Tehran: Amir Kabir publications.

Nafisi, A. A. (1938). Nafisi Dictionary (Froughi, M. A. Ed.). Tehran: Color printing Co.

Padshah, M. (1956). Farhang Anandaraj (Siaghi, M. D. Ed.). Tehran: Khayyam Publication.

Qalqashandi, A. (2008). Subh al-a'shā (Vol. 2). Beirout: Daralfekr.

Rampouri, G. (1984). Ghiasolloghat rampouri (Servat M. Ed.). Tehran: Amir Kabir Publications.

Rouni, A. (1968). Divan (Damghani, M. Ed.). Mashhad: Bastan Bookdeller. 
Safa, Z. (1993). Literary History. Tehran: Ferdous Publication.

safipour, A. R. (1917). Montaha-al-erab fi loghat alarab. Tehran: Sanaie Library.

Shafiei Kadkani, M. R. (1981). Sovar e Khyal (imagery) (3rd ed.). Tehran: Zovar Publications.

Shamisa, S. (1995). Sabk Shenasi Sher (versification). Tehran: Ferdous Publication.

Shamisa, S. (1998). Farhang-e esharat-e adabiat-e Farsi (1st ed.). Tehran: Ferdowsi.

Shamisa, S. (1999). Literary Criticism. Tehran: Ferdous Publication.

Shams Qeis Raazi, M. (1994). Almoajam fi Maaiere Ashare alajam. Tehran: Sokhan Publications.

Tahanawi, M. A. (1996). Kashaf istilahat al-funun wa-al-'ulum. Beirut: Librarie du Liban.

Talebian, Y. (1997). Literary Images in Khorasani Style Poets. Kerman: Emade Kerman Publications.

Zahooro Din, A. (2005). Persin Literary History (Trans. By Shahid Choohdari). Tehran: Tehran Publications.

\section{Submit or recommend next manuscript to SCIRP and we will provide best service} for you:

Accepting pre-submission inquiries through Email, Facebook, LinkedIn, Twitter, etc. A wide selection of journals (inclusive of 9 subjects, more than 200 journals)

Providing 24-hour high-quality service

User-friendly online submission system

Fair and swift peer-review system

Efficient typesetting and proofreading procedure

Display of the result of downloads and visits, as well as the number of cited articles

Maximum dissemination of your research work

Submit your manuscript at: http://papersubmission.scirp.org/

Or contact ojml@scirp.org 